\title{
Labor outsourcing: between efficiency and social equity
}

\author{
La externalización de trabajo: entre la eficiencia y la equidad social
}

\author{
Camilo Piedrahita Vargas* \\ Head of EAFIT University Law School (Medellin, Colombia). cpiedra8@eafit.edu.co \\ Martha Elisa Monsalve** \\ Graduate and undergraduate Professor of labor law and social security law La Gran \\ Colombia University Law School (Bogotá, Colombia). malisa29mon@hotmail.com
}

\begin{abstract}
Production models have changed considerably from a paradigm based in internalize as many processes and business activities to models based in subcontracting or outsourcing, where companies engage only what is commonly called as "the core" business.

Outsourcing or subcontracting is usually positive to produce the so-called "market exchange efficiency", however, it can also be a vehicle for lack of minimum labor standards. Colombia's labor market has not been immune to this phenomenon. The abuse of these mechanisms have generated strong measures to restrict any practice of outsourcing or subcontracting, including those that seem rational or efficient.

The goal of this paper is to identify how production models have turned to an outsourced model in Colombia as an expression of labor flexibility demands; which institutional mechanisms have been used (or abused) to apply that model into human resource provision and how efficient result the strategies that restrict this model.
\end{abstract}

Keywords: Labor outsourcing, labor flexibility, subcontracting, labor efficiency, labor market.

\section{Resumen}

Los modelos de producción han cambiado de una internalización de las actividades, a modelos basados en la subcontratación o la externalización, donde las empresas contratan lo que comúnmente se conoce como "el core" del negocio. La externalización o la subcontratación son por lo general figuras positivas para lograr la eficiencia del mercado, sin embargo, también pueden ser un vehículo que conlleva a la ausencia de estándares mínimos de protección laboral.

Colombia no ha sido inmune a este fenómeno, el abuso de estos mecanismos ha llevado a la creación de medidas para restringir cualquier práctica de externalización o subcontratación, incluyendo aquellas que parecen racionales.

El objetivo de este artículo es identificar como los modelos de producción han pasado a ser modelos de externalización como expresión de flexibilización laboral; qué mecanismos institucionales han sido usados (o abusados) y qué tan eficiente ha sido el resultado de las estrategias que lo restringen.

Palabras clave: Externalización laboral, flexibilidad laboral, subcontratación, eficiencia laboral, mercado de trabajo.

\section{Labor flexibility, outsourcing and implications ${ }^{1}$}

Labor flexibility analysis, supposes start whit noticing the last thirty year process of welfare state conceptions, which tended by a state intervention that provides everything that is necessary to fulfill the individual needs.

$\overline{1 \text { This chapter is based }}$ on the results of institutional research named : "Las cooperativas de trabajo asociado como fenómeno de flexibilización y su impacto sobre los derechos mínimos laborales" performed at University of Medellín by Eraclio Arenas Gallego, Camilo Piedrahita Vargas y Juan Miguel Plata López. 
These conceptions have been being replaced by neo-liberal and neo-institutional economic ideas that promote a model whit no state intervention in trade and production relations, which should be governed by freely fluctuating supply and demand forces, and labor relations, which must follow the same process of easing mainly through deregulation of labor law. Neoliberalism ultimately finds its ideological basis in the Lutheran and Calvinist positions which promote a free individual who works for himself and for his community but not dependent on it (live for society, not society).

Moreover the transition from traditional production models, such as the FordistTaylorist, which was based on the development of products in series with an allocation of specific tasks to workers, appears. Actually, production processes aim to the realization of services, rather than goods, products whit a huge level of complexity for a global market that fluctuates rapidly with qualified employees performing functions in different areas of the organization supported by an accelerated growth of technological tools. The entry of new Asian supremacy in the labor market with their modern system of production and cheap labor has changed the paradigms of production systems.

The labor market has been growing worldwide; first with the entrance of women in a meaningful way; then the youth population, which has created a new need for temporary jobs.

The political, cultural and technological economic modernization has imposed on all states and their companies, the obligation to enter the era of a globalized world in which relations between businesses, governments and individuals are not as rigid as they used to be, through reforms of state structures, their political-economic models and its regulations.

Finally the problems related to unemployment, underemployment, insecurity and stability in labor markets, demand new forms and methods of work that will generate resources in the real sector of the state economy to enhance mobility of lines of consumption and production. This position is based on the neoclassical conception of economics that blames rigidity of labor market as the cause of high unemployment, which is reflected in the legal rules and regulations as the product of state intervention in the economy.

For neoclassical followers, the solution to unemployment problems involves flexibility in the labor market and the arrangements for recruitment of the workforce, because of a free trade vision and a non-interventionist State. Under this scenario, according to neoclassical conception, the oversupply of labor (unemployment) would generate a fall in the price of it until you reach a point at which an equilibrium price and optimum levels of employment occurs.

However for Keynesian economic theory fans, which advocates for state interventionism, the neoclassical solution is not perfectly applicable to labor markets due to there is no perfect method or model of workers in different sectors of production and also for being the income of workers the relevant variable, which commits their own subsistence, no autonomy of decisions regarding salary amounts can be predicated. Because of this, before flexibility and not intervention of the state in regulating the labor market, the followers of the Keynesian school support a position of intervention and regulation.

On the other hand, the gigantic economic, political, social, cultural and technological changes have forced States, to ideate models, strategies and regulations in order to progress at the same pace as the rest of the world. That said it is clear that flexibility phenomenon is imminent for all states and there is no way to avoid it without companies, individuals or States to suffer the consequences of lag in political, economic, legal and commercial matters. 
"Flexibility (labor) is the ability of individuals in the economy and in particular in the labor market to give up their habits and adapt to new circumstances" (Álvarez, 1993, p 4-9). "( ) for labor flexibility we understand the widespread tendency to modify unilaterally or heteronomous legal rules providing work, altering the levels of existing worker protection in order to adjust labor input to the new demands of the production system" (Raso, 1993, p.383-418).

After analyzing previous definitions we can say that flexibility necessarily implies the modification not only of the legal regulations, but State structures, macro and micro political and economic modernization, and access to technology in order to adapt production to new trends of globalization and trade integration, and thus, ensure sustainable economic growth that would meet the fundamental objective of the economy, which is to provide the greatest possible comfort to humans through maximization models scarce resources.

Several authors such as John Atkinson who distinguishes four types of labor flexibility, have classified conceptually flexible labor market.

Numerical flexibility, which enables businesses to adapt the number of workers and their work hours according to variations in demand.

Functional flexibility, which allows companies to reorganize the workplace for employees to make a greater number of functions within its capabilities and experience.

Third is related to the phenomenon of outsourcing and the resulting decline in labor recruitment breaking through to another type of hiring civil, commercial, etc. Finally the geographical and occupational mobility of workers. (Atkinson, 1984),

Labor flexibility does not appear in a unique scenario, several varieties of this phenomenon are presented according to the 2 The original text is written in spanish. This is a free translation made by the authors. scope and relationships in which it occurs. First, there is a demand for softer salary and compensation regulations, which seeks to reduce the possible rigidities associated with the hiring and length of the working day reflected in earnings.

Secondly appears flexibility related to the collective organizations of workers (unions) which tries to avoid the rigidities arising from the conquers of union bargaining.

In the third place appears flexibility in terms of the characteristics of technology and products which aims at transforming production models through the entry of new technologies which results in the acquisition of qualified employees who produce a broader range of products by using several tools, which meets the requirements of a much larger and permanently changing market.

Fourthly, a liberalization process appears as the employer faculties of labor consumption, which occurs when technology is embraced by the industry, changing it working needs, going from employees who are specifically prepared and resistant to change to multi-functional employees.

Flexibility also results in terms of business organization, as a mechanism to avoid bureaucratic schemes within the company and move to new models where some initiatives recognize and reward workers who seek to stimulate inventive and re invest their knowledge to their productive experience.

As a result of labor flexibility demands, outsourcing is a business operation model involving "outside" providing of goods and services, through the market (price system) as an opposition to the internal execution or production of the good or service as a process or activity of the company; as a result of specialized economies, where every entrepreneur focuses on what constitutes its "core business" and / or competitive advantage, leaving the rest of 
activities to other (employers) who can do it better and at lower cost.

Outsourcing involves finding new suppliers and new ways to ensure delivery of raw materials, items, components and services. It means using the knowledge, experience and creativity of new suppliers who previously would not apply.

Therefore, the term outsourcing is synonymous with others as "thinned administration", "joint manufacturing companies" and "co-manufacturing".

This decision to transfer to another company one of the processes or activities, has increased in recent years as the benefits of specialization had been identified and a huge number of problems associated with the operation of a large company have been revealed.

What was previously considerate as an advantage in large companies, today is an affection by the "paralysis of motion", where companies tend to be inflexible with jobs that reduce creativity and innovation.

The company then faces the decision to produce or perform a process by itself or provide it externally. If the company decides to make or manufacture it itself, costs associated with the inefficiency for doing something that someone else could do better and cheaper, thanks to the specialization it may occur; also those associated with labor rules (direct and indirect), as the need for more workers and bear the indirect costs such as unionization, sickness, maternity, job security etc. Finally it should be noted that (the administrator) business function, which replaces the market or price mechanism when the company decides to do something for itself and not by an external partner, has diminishing marginal returns, this means that assuming a process or additional activity, the proper management capacity decreases.

All this constitutes a powerful incentive for many companies to create a model based in outsourcing; due to its capacity to reduce labor costs, the traditional response from labor authorities has been to restrict, limit, or even prohibit outsourcing, presuming that in most cases, the companies use this model because of the perverse incentive, letting aside efficiency analysis. This other vision realizes that due to specialization, providing a good or service through a third party is efficient for the company and therefore to society, according to the theory of market exchange efficiency.

For the Chicago School of economic analysis of law (which refers to neoclassical microeconomics theory), the (free) market is an efficient mechanism for an efficient allocation and reallocation of resources, carrying goods and services from the hands of the people that less value them, or from their less valuable uses to those who value them the most (or the most valuable uses).

For this school, one of the objectives or purposes of the law is (or should be) efficiency generation or at least, not generating inefficiencies, and therefore, law should not restrict or prohibit efficient transactions.

These postulates are applicable to legal or administrative restrictions concerning labor outsourcing. As can be seen, many of these restricted transactions, limited or even banned, could be efficient under the Pareto criteria, however, employer acting based on the perverse incentive to reduce (at all costs) labor costs fear, leads to institutional remedies that result in not recoverable efficiency costs for society.

The challenge for government authorities is to identify which outsourcing practices are efficient and not evil, to allow the first and restrict the latter. Usually the market regulator takes command and control measures to prohibit undesirable behavior (such as outsourcing). This type of regulatory strategies tend to have a high cost of monitoring and therefore low levels of efficacy; alternative incentives (economic, monetary) to the internalization of business processes and 
activities that reduce to a minimum the perverse incentives, using a cost - benefit analysis, where the company decides for efficiency seem to be a better approach.

Itisnecessary to take intoaccountin this analysisthat a rational firm, (selfish, rational and who maximizes its own benefit), as neoclassical microeconomics and the Chicago School conceived it, should not immediately opt for outsourcing.

This rational company should consider that using the market (price mechanism) also causes representative costs. First, the price mechanism involves a loss of control because the good or service is produced or provided by a third party, so the entrepreneur is unable to control aspects such as quality, time delivery, etc. This cost in turn implies that the company has to raise its level of surveillance (monitoring cost) on that what the contractor or provider is making for him. Third, the market involves taking the so-called transaction costs, as searching, selection and hiring suppliers, as well as monitoring those agreements.

To reduce these transaction costs (of contracting) the employer may choose to perform long-term contracts and thus reduce the number of negotiations, and the level of uncertainty. However, this practice is very complex especially in the procurement of services, due to uncertainty about market behavior and the contractor needs in the future, what makes these contracts extremely generic and increase compliance costs thereof.

Finally, using the market may involve additional taxes that domestic business does not assume.

Ronald Coase presented this analysis in his paper named "The nature of the firm" (Coase. 1937), in these terms:

The main reason why it is profitable to establish a firm would seem to be that there is a cost of using the price mechanism. The most obvious cost of "organizing" production through the price mechanism is that of discovering what the relevant prices are. This cost may be reduced but it will not be eliminated by the emergence of specialists who will sell this information. The costs of negotiating and concluding a separate contract for each exchange transaction which takes place on a market must also be taken into account. Again, in certain markets, produce ex-changes, a technique is devised for minimizing these contract costs; but they are not eliminated. It is true that contracts are not eliminated when there is a firm but they are greatly reduced. A factor of production (or the owner thereof) does not have to make a series of contracts with the factors with whom he is co-operating within the firm, as would be necessary, of course, if this co-operation were as a direct result of the working of the price mechanism. For this series of contracts is substituted one. At this stage, it is important to note the character of the contract into which a factor enters that is employed within a firm. The contract is one whereby the factor, for a certain remuneration (which may be fixed or fluctuating), agrees to obey the directions of an entrepreneur within certain limits. 20 The essence of the contract is that it should only state the limits to the powers of the entrepreneur; within these limits, he can therefore direct the other factors of production.

There are, however, other disadvantages - or costs - of using the price mechanism. It may be desired to make a long-term contract for the supply of some article or service. This may be due to the fact that if one contract is made for a longer period, instead of several shorter ones, then certain costs of making each contract will be avoided. Or, owing to the risk attitude of the people concerned, they may prefer to make a long rather than a short-term contract. Now, owing to the difficulty of forecasting, the longer the period of the contract is for the supply of the commodity or service, the less possible, and indeed, the less desirable it is for the person purchasing to specify what the other contracting party is expected to 
do. It may well be a matter of indifference to the person supplying the service or commodity which of several courses of action is taken, but not to the purchaser of that service or commodity. But the purchaser will not know which of these several courses he will want the supplier to take. Therefore, the service that is being provided is expressed in general terms, the exact details being left until a later date. All that is stated in the contract is the limits to what the persons supplying the commodity or service is expected to do. The details of what the supplier is expected to do is not stated in the contract but is decided later by the purchaser. When the direction of resources (within the limits of the contract) becomes dependent on the buyer in this way, that relationship which I term a "firm" may be obtained. 21 A firm is likely therefore to emerge in those cases where a very short-term contract would be unsatisfactory. It is obviously of more importance in the case of services -laborthan it is in the case of the buying of commodities. In the case of commodities, the main items can be stated in advance and the details which will be decided later will be of minor significance".

In conclusion, the premise that all employers desire using the market (outsourcing) instead of assuming another activity, and especially to violate labor rights or privileges is not necessary rational from this economic perspective. The size of a company (in terms of how many activities it operates within it) is not a decision only produced by perverse incentives; in Coase's words: "To determine the size of the firm, we have to consider the marketing costs (that is, the costs of using the price mechanism), and the costs of organizing the different entrepreneurs and then we can determine how many products will be produced by each firm and how much of each it will produce".

\section{Outsourcing tips}

If the company decides to outsource, due to the explanations given above, it should take in account:
Real costs should be determined; not only the cost of assuming that activity within the company but those associated to provide the service or good through the market (in a three year time line, at least).

About the relation with the outsourcer, the company should think about issues like, ¿what if I develop another business line? ¿Is it possible to re-negotiate with de contractor? ¿What if I do not compliance the agreement? ¿Which are the consequences?

Outsourcing usually generates a lot of uncertainty; clients and workers should be informed and prepared to assume the new conditions derived from it.

What to outsource:

- Operations that make intensive use of resources.

- Relatively independent areas.

- Specialized services or support services.

- Operations with fluctuating patterns of workload and performance.

- Transactions subject to a rapidly changing and where it is costly to recruit, train market, and retain staff.

- Activities working with rapidly changing technology that requires great investment.

- What should not be outsourced:

- Management of strategic planning.

- Finance management.

- Administrative management consulting.

- Control of suppliers.

- Quality management and environmental management

- Monitoring the satisfaction of market and regulatory requirements such as: product liability, misleading advertising, quality, environmental regulations, personal hygiene, safety and security issues 


\section{About Colombian labor market}

\section{Labor flexibility methods}

\section{Short-term contracts}

Colombian labor law admits definite period contracts. In this cases employer must make a 30-day advice previous to be authorized to cancel the contract once it has arrived to its established term. Additionally, employer and worker can renew the contract for the same term (or lower) in the first three opportunities (after the ending of the first contract term); or for a minimum of a year or a maximum of three years, after those first three periods.

This means that there is a huge liberty for definite term contracts, which not stimulate long-term contracts.

\section{Temporary services companies}

This figure allows companies that need labor for a short period, like those who need to replace a sick worker, or those who deal whit a production peak ( for one year at last) to acquire this worker trough another company, called a temporary services company (TSC). In these cases, the worked is hired by the TSC, and sent to work in another company (called the user company); this last company has at all the TSC, which has a labor relation with the worker.

The problem with this strategy is that this type of workers does not have the labor (conventional) prerogatives that direct workers of the user company have. This evil incentive increases the use of this figure more than social desirable, even in cases that are not permitted by law, as a cost reduction method.

\section{Associated work cooperatives}

Since the last years of the 1970's decade, Colombia created a hybrid system of labor purchasing.

Associated work cooperatives, started as a figure than involved an association of persons who did not have capital, but only work. Like a corporation in which shareholders do not have to put money, just work; at the same time, these persons were owners of the company and workers. Due to this condition, labor standards did not apply to them. This perverse incentive leads many companies to abuse of this figure, creating their own cooperatives, and satisfying their labor demands without any labor standards. Numbers about cooperative workers growth are impressive; they will be analyzed later. Because of this abuse, United States government demanded Colombian government actions to control this type of "social" entities during the free trade agreement negotiations (a country that produces cheaper is more competitive in this scenario).

\section{Outsourcing}

This figure implies that a company contracts (through a commercial agreement) another company or person to provide a service or manufacture a good. This contracted company or person has total managerial autonomy; to prevent that companies create their own outsourced companies or using them to avoid labor standards, legal solidarity between the contractor and the owner of the work is placed.

\section{Labor statistics}

During the first decade of this century (2002 -2010), the Colombian labor market has been characterized by a better rate of occupancy (which increased from $51 \%$ to $56 \%$ ), which means that the market has generated more jobs which appears consistent with economic growth in the same period (average growth rate of 4.4). However, during this period, atypical contracts (outsourcing, cooperatives) grew considerably. These jobs usually involve inferior levels of stability and income; therefore, it is likely that despite the number of jobs created, the quality conditions thereof are not equally positive.

International Labor Organization involving at least four factors defines Job quality (decent 
work): compliance with international labor standards and fundamental rights; employment opportunities; social protection and social dialogue.

Regarding the quantitative dimension, the employment rate rose from $52 \%$ to $55.8 \%$ in the first decade of this century; informality rate fall from $60 \%$ to $57.2 \%$.

During 2002-2010, cooperative workers number grew in $527 \%$. Outsourcing went from $8 \%$ to $19.6 \%$. However, job stability stay still: both, in 2002 and 2010, 65\% of workers answered that they had been working for the same company at least in the last twelve months.

Social security affiliation data shows some progress in the analyzed period. Health system contributors increased from $39.6 \%$ to $42.5 \%$ and pension funds affiliates passed from $29.8 \%$ to $37.1 \%$.

The biggest setback occurred in social dialogue; in 2002, 432,729 workers were company unionized; by 2010 , only 375,122 . The total number of unionized workers (all union types) decreased from 863,591 in 2002 to 810,193 in 2010 (union rate is under $3 \%$ ).

The underemployment rate reported a slight positive report going from $40.3 \%$ in 2001 to $37.4 \%$ in 2010 .

Finally, work and family life conciliation remained constant; in 2002, 30\% of workers considered having long working hours; by 2010 , this number was $29.5 \%$.

\section{As a conclusion}

The expansion of labor flexibility did not bring the feared harmful effects on the quality conditions of employment but also did not allowed expected positive effects of economic growth over the labor market conditions (Farné, 2012). Therefore, labor regulations restricting efficient transactions should be the last resort to achieve workers' rights protection; instead, labor markets surveillance by administrative authorities is recommended.

\section{References}

Álvarez Pereira, Carlos. Flexibilización de la Normatividad Laboral: Balance de la Reforma Laboral, Ley 50 de 1990. En: Revista Actualidad Laboral y Seguridad Social $N^{\circ}$ 58. Bogotá. Editorial LEGIS. Julio - Agosto de 1993. Págs. 4 - 9. [link]

Atkinson, John. Manpower strategies for flexible organizations. Personnel Management, August. Pp 28-31 [impreso]

Coase, Ronald. The Nature of the Firm. Económica, New Series, Vol. 4, No. 16. 1937. pp. 386-405. [link]

Farné, Stefano (comp). La calidad del empleo en América Latina a principios del siglo $X X I$. Universidad Externado de Colombia, Bogotá. 2012. [link]

Raso Delgue, Juan. Flexibilización: Desregulación o adaptación del Derecho del Trabajo. En: Revista de la Facultad de Ciencias Jurídicas y Políticas $\mathrm{N}^{\circ} 87$. Caracas: Universidad Central. 1993. Págs. 383 - 418. [impreso] 